\title{
Preparation of Sterculia foetida - pullulan based semi- interpenetrating polymer network gastroretentive microspheres of amoxicillin trihydrate and optimization by response surface methodology
}

\section{Sterculia foetida - pullulan esaslı yarı iç içe geçmeli polimer ağı gastroretentif amoksisilin trihidrat mikrosferlerinin hazırlanması ve yanıt yüzey metodolojisi ile optimizasyonu}

\author{
Shagufta Khan*, Jayshri Hadke \\ Pharmaceutics, Institute of pharmaceutical Education and Research, Wardha, India
}

\begin{abstract}
INTRODUCTION: In the current investigation a novel sterculia foetida and pullulan based semiinterpenetrating polymer network gastroretentive microsphere formulation was prepared by emulsion crosslinking method and optimized by central composite design.

METHODS: The effect of amount of glutraldehyde, sterculia foetida and puliulan on percent drug entrapment efficiency (\% EE), percent mucoadhesion at $12 \mathrm{~h}$ and percent in vitro drug release at $12 \mathrm{~h}(\% \mathrm{Q} 12 \mathrm{~h})$ were optimized. The microspheres were also characterized by SEM, FTIR and DSC.
\end{abstract}

RESULTS: The formulation containing $4 \% \mathrm{v} / \mathrm{v}$ Glutraldehyde, $8.28 \% \mathrm{w} / \mathrm{v}$ pullulan and $2.14 \%$ w/v sterculia foetida had $88.75 \pm 1.18 \% \mathrm{EF}$, gave $80.43 \pm 1.2 \%$ drug release in $12 \mathrm{~h}$ and $81.73 \pm$ $1.50 \%$ mucoadhesion at $12 \mathrm{~h}$ was considered optimum and was used for in-vivo radiographic study.

DISCUSSION AND CONCLUSION: From the study it was concluded that semiinterpenetrating polymer network microspheres loaded with amoxicillin trihydrate were successfully prepared using Sterculia foetida and pullulan gum. The prolong retention of microspheres in the stomach with sustained drug release could effectively act against the $\mathrm{H}$ Pyroli reservoir in the stomach and improve the therapeutic effectiveness of amoxicillin trihydrate against H-Pyroli.

Keywords: Sterculia foetida, pullulan, semi-IPN, central composite design, In-vivo radiographic study

Öz

GÍRIŞ ve AMAÇ: Mevcut araştırmada, yeni bir sterculia foetida ve pullulan bazlı yarı iç polimer polimer ağ gastroretentif mikrosfer formülasyonu, emülsiyon çapraz bağlama yöntemiyle hazırlandı ve merkezi kompozit tasarım ile optimize edildi.

YÖNTEM ve GEREÇLER: Glutraldehit, sterculia foetida ve pullulan miktarının yüzde ilaç tutma etkinliği (\% EE), yüzde 12 'de yüzde mukoadhezyon ve yüzde 12 'de (\% Q12h) in vitro ilaç salımı üzerindeki etkisi optimize edilmiştir.Mikro küreler ayrıca SEM, FTIR ve DSC ile de tanimland1.

BULGULAR: $\% 4 \mathrm{~h} / \mathrm{h}$ Glutdehid, $\%$ 8,28 h / h pullulan ve $\%$ 2, $14 \mathrm{~h} / \mathrm{h}$ sterculia foetida içeren formülasyon, $\% 88,75 \pm 1,18$ EF'ye sahipti, 12 saat içinde $\% 80,43 \pm \%$ 1,2 ilaç salımı ve 12 saat içinde $\%$ 81,73 $\pm 1,50$ mukoza yapışması verdi optimum olarak kabul edildi ve in-vivo radyografik çalışma için kullanıldı.

TARTIŞMA ve SONUÇ: Çalışmadan amoksisilin trihidrat yüklü yüklü iç içe geçen polimer ağ mikrosferlerinin Sterculia foetida ve pullulan zamkı kullanılarak başarıyla hazırlandığı sonucuna varıldı.Mide içerisinde sürekli ilaç salımı ile mikro kürelerin uzun süre tutulması, midedeki HPyroli rezervuarına etkili bir şekilde etki edebilir ve amoksisilin trihidratın H-Pyroli'ye karşı terapötik etkinliğini artırabilir.

Anahtar Kelimeler: Sterculia foetida, pullulan, yarı IPN, merkezi kompozit tasarım, In-vivo radyografik inceleme 
07152-240284

0000-0002-2827-7939

17.11.2019

14.01.2020

\section{Introduction}

Number of disease conditions demands development of controlled and targeted drug delivery systems. Pharmaceutical technology is continuously expanding for providing a sustainable, constant level of drug at the therapeutic optimal in the blood circulation. Drugs whose absorption site is upper gastrointestinal tract or which suffer from stability issue can be benefited when they are framed in the form of mucoadhesive microspheres ${ }^{1}$. Mucoadhesive microspheres have ability to adhere them in a particular absorptive part of the gastrointestinal region, thus improves rate of drug absorption and enhance bioavailability. Microspheres size allows them to remain entangle in stomach mucosal lining for longer duration of time.

Mucoadhesive microspheres, due to gastroretention may build high drug concentration in the stomach mucosa, which may be valuable for eradication of peptic ulcer caused due to $H$. pylori. ${ }^{2}$ Warren and Marshall have pointed out that $H$. pylori manifestations predominately affect the gastrointestinal tract causing inflammation of stomach, duodenal ulcer, gastric ulcer and gastric carcinoma. Study reported that $H$. pylori infection is responsible for causing $90-100 \%$ duodenal ulcer and $60-90 \%$ of gastric ulcer in patients infected with $H$. pylori. Literature survey reported that $H$. pylori infection increases possibility of developing peptic ulcers and $10-15 \%$ of individuals infected with $H$. pylori will have more chance of peptic ulcer disease throughout out their life ${ }^{3}$.

Amoxicillin trihydrate is the semi-synthetic antibiotic widely recognized to be effective in treating peptic ulcer disease induced by H. pylori. It is one of the major components of standard therapy. It is used in combination with others antibiotic along with antacids. Clinically it is found to be effective but due to drug related problems and increase in resistance to antibiotics success rate for full eradication of $H$. pylori with conventional therapies is decreasing. Amoxicillin is acid-soluble drug which creates a problem of controlling its release for longer time period in the acidic environment of the stomach. H. pylori once colonized in acidic stomach environment penetrate in deeper mucus membrane of stomach which is bacterium's niche due to good motility of flagellae. In addition to this, $H$. pylori possess certain adhesion which can fix themselves with lipids and carbohydrates of membrane which helps it to hold to the epithelial cells. Several studies and reviews recommended that local drug delivery work more effectively than systemically given antibiotics for eradication of $H$. pylori. Drug delivery system should have ability to release drug in the vicinity of stomach lining which demands designing of such a drug delivery systems that can overcome not only the problems of conventional delivery system but also should possess ability for delivering the antimicrobial agents to the infected cell lines. Mucoadhesive microspheres have ability to adheres with gastric mucosa, and thereby they releases drug in continuous manner thus they can be more effective against H. pylori. ${ }^{4,5}$ Natural hydrophilic polymers possess structural flexibility, thus can be used in framing oral controlle release drug delivery system which provides desirable drug release profile ${ }^{6}$. Sterculia foetida is medicinally important polysaccharides obtained in the form of exudates from Sterculia urens, a simall to medium size bushy tree which belongs to the Sterculiaceae family. It fixes itself with water molecules though not in fully soluble form but it can swell leading to increase in total volume in relation to dry mass which is 60 times more than the original volume. It possess ramnogalacturonane-type partially-acetylated ramified structure and it's molecular weight is 16 X $103 \mathrm{kDa}$ and chemically it consist of $55-60 \%$ of unbiased monosaccharide units (galactose and ramnose), $8 \%$ of acetyl groups and $37-40 \%$ of acid residues (galacturonic and glucuronic acids). Core part of structure is $\alpha$-D-galacturonic acid and L-ramnose units ${ }^{7}$. Sterculia foetida has several potential commercial applications, primarily in the food and pharmaceutical industries. It is edible, odorless, and flavorless, thus it is used as a food additive.. As a result of its bioadhesive, non-toxic, nonimmunogenic, non-mutagenic and non-carcinogenic properties ${ }^{8,9}$. It is being considered as a promising biopolymer for the development of drug-loaded microparticles. Sterculia foetida shows good swelling properties and is able to modify the drug release from the polymeric matrix ${ }^{10}$. In an investigation, sterculia foetida was blended with pectin to produce a sustained release carrier having floating ability and increasing gastric residence ${ }^{11}$. 
Currently, for pharmaceutical industry Sterculia foetida is one of the most promising plant polysaccharides. It shows acid stability due to presence of acetyl groups in its structure. It also possesses admirable swelling capacity, good mucoadhesive and biodegradable properties. Various studies reported use of Sterculia foetida in treating ulcers, irritable bowel disorder, persistant colonic diseases reducing cholesterol and improving glucose metabolism without badly affecting most mineral balances. Many scientists in their research have formulated interpenetrating polymer network microspheres using polysaccharides and reported that it can be used for sustained drug delivery ${ }^{12}$.

Recently, more attention is also being given towards polysaccharides acquired from microorganisms and yeast. Pullulan is neutral homopolysaccharide of glucose consisting of repeating maltotriose residues connected by $\alpha-1,6$ glycosidic bonds and some interspersed maltotetraose units produced by fungus Aureobasidium pullulans. Pullulan has additional advantages of bio compatibility, non-toxicity, non-immunogenicity, non-mutagenicity and noncarcinogenicity. Pullulan is also used as binder, thickeners, lubricant and gelling agent. Due to its unique linkage pattern it has ability to capture biological molecules and it has exceptional oxygen barrier properties which increases stability of these molecules with increased shelf-life. Pullulan is highly soluble in water thus can be used as drug carrier, however it faces uncontrolled hydration and drug release related issues, which has restricted its applications. Hydrophillicity of pullulan can be reduced by crosslinking it with anionic polymer like Sterculia foetida. Besides this, pullulan can be cross-linked easily by glutaraldehyde and addition of Sterculia foetida will give attractive combination to increase its mechanical strength ${ }^{13}$.

Number of naturally occurring polysaccharides through formation of interpenetrating polymeric networks (IPNs) improved mechanical strength and gave desired release behavior of entrapped drug. The reported IPN involves interaction between Delonix regia gum and sodium alginate ${ }^{14}$, calcium pectinate and tamarind seed gum ${ }^{15}$, carrageenan-Alginate ${ }^{16}$, locust bean gum and alginate $^{17}$, guar gum and chitosan ${ }^{18}$, carboxymethyl xanthan and alginate ${ }^{19}$ etc. No attempt has been made yet to formulate semi-IPN microspheres involving pullulan with Sterculia foetida. Therefore, in the current investigation an attempt has been made to formulate Sterculia foetida pullulan based semi-IPN microspheres for stomach specific delivery of amoxicillin trihydrate ${ }_{2}$ which can provide good mechanical strength and prevent uncontrolled water uptake and, will remain in the stomach to provide release over long periods for activity against $H$. pyroli. It is proposed that Sterculia foetida have anti-ulcer property this could act synergistically against $H$. pylori along with amoxicillin trihydrate.

\section{Experimental part Materials}

Amoxicillin Trihydrate was procured as a gift sample from Ranbaxy Laboratories (Goregaon, East Mumbai, and India), Pullulan having Molecular weight 200,000 Da was procured from Kumar Organic Products Limited Bangalore, India. Sterculia foetida was gifted by Research Lab Fine Chem, Industries, (Mumbai, India), Light liquid paraffin (LLP), was supplied by Hi Media Laboratories Private Limited, Mumbai.(India). Pioneer In-Organics supplied Span 80 (Delhi, India), Glutaraldehyde (25\%, v/v) was procured from Merck Limited, (Mumbai,India).Dichloromethane was obtained from Loba Chem. Private limited, Mumbai(India), All other reagents used in experimental work were of analytical grade.

\section{Preparation of Sterculia foetida and pullulan blend semi-IPN microspheres}

Water-in-oil (w/o) emulsion crosslinking technique was used for preparation of Sterculia foetida and pullulan based semi-IPN microspheres containing amoxicillin trihydrate (ASP-MPs) ${ }^{20}$.

Sterculia foetida and pullulan were kept for hydration in distilled water. These two polymeric solutions were mixed and it was stirred well so that homogenous solution should form. To this polymeric solution drug was incorporated and solution was uniformly mixed on magnetic stirrer so that homogeneous, bubble free drug polymer mixture should formed. The drug containing polymeric mixture was then gradually added to light liquid paraffin under constant mechanical stirring at $2000 \mathrm{rpm}$ for $10 \mathrm{~min}$. Span-80(1\%) was previously added to polymeric solution. After formation of a milky white emulsion different amount of glutaraldehyde (GA) containing $0.5 \mathrm{ml}$ of $1 \mathrm{~N} \mathrm{HCl}$ was added gradually and resulting emulsion was stirred was continuously for $2 \mathrm{~h}$ for getting hardened microspheres. The microspheres were then filtered and washing was done with dichloromethane for removal of excess amount of liquid paraffin, and subsequently were washed several times with water to remove un-reacted GA. Resulting microspheres were then allowed to dry under vacuum at $40^{\circ} \mathrm{C}$ and finally they were stored in desiccators until further use. 


\section{Experimental design for optimization of MP formulation}

In the current work ASP-MPs were prepared and optimized using three factors and three-level randomised central composite design in order to find out effect of process variables on the prepared microspheres. The three independent variables, volume of crosslinker GA (A), amount of pullulan (B) and Sterculia foetida (C) were varied at three levels as shown in table no.1. Statistical trial design was generated and evaluated by Design-Expert ${ }^{\circledR}$ Version11.0.3.0 software (Stat-Ease Inc., USA). Percent drug entrapment efficiency, cumulative percent drug release for $12 \mathrm{~h}$ and percent mucoadhesion were selected as dependant variables. Design matrices showing effect of independent variables on studied responses (dependent variables) are given in table no. 2 and response surface plots are shown in Figure no. 1a-c. Optimization was done by modeling effect of independent variables on the responses by using quadratic mathematical model as shown in equation 1 and constraints on responses were maximum entrapment efficiency, maximum drug content and maximum mucoadhesion ${ }^{21,22}$.

$\mathrm{Y}_{0}=\mathrm{b}_{0}+\mathrm{b}_{1} \mathrm{~A}+\mathrm{b}_{2} \mathrm{~B}+\mathrm{b}_{3} \mathrm{C}+\mathrm{b}_{12} \mathrm{AB}+\mathrm{b}_{13} \mathrm{AC}+\mathrm{b}_{23} \mathrm{BC}+\mathrm{b}_{11} \mathrm{~A}_{2}+\mathrm{b}_{22} \mathrm{~B}_{2}+\mathrm{b}_{33} \mathrm{C}_{2}$

Where, $\mathrm{Y}$ is the response; $\mathrm{b}_{0}$ is the intercept and $\mathrm{A}, \mathrm{B}$ and $\mathrm{C}$ are the independent formulation variables.

\section{Characterization of ASP-MPS}

\section{Fourier transforms infrared spectrum study (FT- IR)}

FTIR spectrophotometer (Shimadzu Asia Pacific Pvt. Ltd. Singapore, Model No - 84005) in the range of 4000-400 $\mathrm{cm}^{-1}$ using $\mathrm{KBr}$ pellets was used for recording of Fourier transform infrared (FT-IR) spectrum of Sterculia foetida gum, pullulan, amoxicillin trihydrate, physical mixture of Sterculia foetida and pullulan with amoxicillin trihydrate and ASP-MPS (Figure no.2).

\section{Differential scanning calorimetry (DSC)}

Thermal stability and crystalline characteristics of Sterculia foetida gum, pullulan, physical mixture of Sterculia foetida, pullulan with amoxicillin trilhydrate and ASP-MPs were studied using differential scanning calorimetry (Mettler Toledo AG, Analytical, Switzerland) at heating rate of $10^{\circ} \mathrm{C} / \mathrm{min}$ in the range of $0-400^{\circ} \mathrm{C}$ (Figure no. 3). Analysis was carried under nitrogen purge $(50 \mathrm{ml} / \mathrm{min})$.

\section{X-ray diffractometry (XRD)}

X-ray powder diffraction (XRD) studies were carried out to study crystal characteristics of amoxicillin trihydrate. (Bruker model D8 advance theta/2theta) using CuKa radiation source at $\mathrm{k}^{1 / 41.5406} \AA$ was used for study. Scan parameters were kept at $5^{0} / \mathrm{min}$ scan speed and increment at 0.02 . A diffraction pattern from $0-80^{\circ} \mathrm{C}$ was recorded at $25^{\circ} \mathrm{C}$. The sample was smeared over low background sample receptacle (amorphous silica holder) and set on the sample stage in goniometer. The current and voltage was place at $40 \mathrm{mV}$ and $35 \mathrm{~mA}$ and data was collected (Figure no. 4).

\section{Determination of particle size and surface morphology analysis}

Required quantity of microspheres was distributed in insoluble solvent and suspension was diluted as per need. One drop of suspension was kept on glass slide which is then examined below microscope for taking a digital picture (DMWBf model, Motic, China). Scanning electron microscopy was carried out by placing the sample on a small piece of adhesive carbon tape which was set on a brass stub. This sample, was then forwarded for gold coating using sputtering unit (model: JFC1600) for $10 \mathrm{sec}$ at $10 \mathrm{~mA}$ of current. The gold coated sample was kept in chamber of SEM (Jeol, JSM 6390LA) and secondary electron images were noted (Figure no. 5).

\section{Determination of percent drug loading and drug entrapment efficiency (DEE)}

Weighed quantity of microspheres $(50 \mathrm{mg})$ were taken, finely powdered and allowed to dissolved in $50 \mathrm{ml}$ of simulated gastric fluid $(\mathrm{pH} 1.2)$ using magnetic stirring at room temperature for $24 \mathrm{~h}$. Resulting suspension was then filtered, suitably diluted and absorbance was taken spectrophotometrically (Shimadzu/UV-1700, Japan) at $229.4 \mathrm{~nm}$. percent drug loading and DEE (\%) were then determined according to the following relationship ${ }^{23}$

Amount of drug in microspheres 


\section{Mucoadhesive study (In vitro) evaluation}

Goat intestinal mucosa was used to study mucoadhesive properties of semi-IPN microspheres. Semi-IPN microspheres dispersion was sprayed on goat mucosa mounted on glass slide. Glass slide was previously incubated by keeping in desiccators $(90 \% \mathrm{RH})$ for $20 \mathrm{~min}$ and then placed in the cell. Finally cell was attached to the outer assembly at an angle of $45^{\circ}$. Simulated Gastric Fluid ( $\mathrm{pH}$ 1.2), was circulated through the cell over the microspheres at a rate of $1 \mathrm{ml} / \mathrm{min}$ with the help of peristaltic pump. Washings were collected after fixed time intervals; microspheres were separated by centrifugation and dried at $40^{\circ} \mathrm{C}$.

The quantity of microspheres washed out was taken and mucoadhesion (\%) was calculated as follows ${ }^{23}$.

Percentage mucoadhesion $=\mathrm{Qa}-\mathrm{Q} 1 \times 100 / \mathrm{Qa}$

Where, Qa = Quantity of microspheres applied initially;

Q1 = Quantity of microspheres leached out

\section{In vitro drug release study}

USP Type-I (basket type) dissolution apparatus (Electrolab, India) was used to determine release of drug in simulated gastric fluid $(\mathrm{pH} 1.2,900 \mathrm{ml})$. Temperature of medium was maintained at $37 \pm 0.5^{\circ} \mathrm{C}$ and speed of $100 \mathrm{rpm}$. Accurately weighed amount of microspheres containing 500 $\mathrm{mg}$ of drug was added in the dissolution medium. After $1 \mathrm{~h}$ interval $1 \mathrm{ml}$ of sample was pipetted out and replaced with fresh medium to maintain sink condition. Pinetted samples were suitably diluted and were analysed by UV-visible spectrophotometry (Shimadzu/UV-1700, Japan) at 229 $\mathrm{nm}$. Dissolution process was carried out for 12 hours. All the release studies were performed in triplicate $(n=3)$ (Figure no. 6). Mathematical kinetic models like zero-order ${ }^{24}$, first-order ${ }^{25}$, Higuchi $^{26}$, and Korsmeyer-Peppas ${ }^{27}$ were used to explore kinetics and drug release mechanics.

\section{In vivo radiographic study.}

To study the location and extent of gastrointestinal transit, ASP-MPs were administered orally to rats and they were monitored by a radiological method. Institutional animal ethical committee had given approval for the study (Protocolno.535/02/a/CPCSEA/S/Jan.2002). Six healthy albino rats of either sex, weighing 400-500 g were used for the present study. The animals were kept in individual cages, and the experiments were conducted in a sanitized room at a temperature maintained around $27 \pm 0.5^{\circ} \mathrm{C}$. Food was withdrawn $12 \mathrm{~h}$ prior to the study with water ad libitum. Radiopaque ASP-MPS were formulated by incorporating $50 \mathrm{mg}$ of barium sulfate into polymeric solution (composition was same as optimized formulation) and ASP-MPs were prepared using a similar procedure as use in formulation of ASP-MPs. ASP-MPs were administered through oral gastric tube with $2 \mathrm{ml}$ water in fasted state. The animals were not allowed to eat throughout the study (up to $12 \mathrm{~h}$ ), $1 \mathrm{ml}$ of water was administered to animals every hour throughout the study. The position of ASP-MPs in the rat's stomach was monitored by X-ray photographs (Siregraph-B, Siemens, Germany) of the gastric region at varying time intervals upto $10 \mathrm{~h}$ (Figure no.7). ${ }^{28}$.

\section{Statistical analysis}

Statistical optimization was done using Design-Expert ${ }^{\circledR}$ Version 8.0.6.1 software (Stat-Ease Inc., USA). All measured data are expressed as mean \pm standard deviation (S.D.). Each measurement was done in triplicate $(n=3)$. Student $t$ test was used to compare two groups ${ }^{29,30}$.

\section{Stability studies}

Stability studies of optimized formulation were carried out as per the ICH guidelines for 6 months ${ }^{31}$. Formulation was packed in a laminated aluminum foil and kept in the stability chamber maintained at a temperature of $40 \pm 2{ }^{\circ} \mathrm{C}$ and $75 \pm 5 \% \mathrm{RH}$. Samples were withdrawn and examined at the end of 1, 3 and 6 months, to check any statistical difference in their 
mucoadhesion, entrapment efficiency and drug content. Differences were considered to be significant at $\mathrm{p}<0.05$.

\section{Results and discussion}

\section{Formulation of microspheres}

In the present investigation ASP-MPs containing amoxicillin trihydrate was prepared using GA as crosslinking agent. Pullulan is highly water soluble polymer when used alone for drug delivery application; it has the property of uncontrolled hydration and film formation which shows abrupt drug release pattern. So, to harness hydration, here Sterculia foetida was interlaced on the pullulan backbone, with the help of GA. Water-soluble GA was chosen as the crosslinking agent because of its ability to facilitate the formation of linkages from hydroxyl groups. The $\mathrm{CHO}$ groups of GA (covalent crosslinker) have ability to react with the -OH groups of Sterculia foetida to form an acetal linkage, leading to the formation of an IPN structure, a three dimensional structure (as evidenced in Figure no.2). The resulting microspheres were insoluble in water with the drug entrapped in the three dimensional polymeric network. In an investigation owing to toxicity concerns of glutaraldehyde as crosslinker, flavonoid like rutin was used to crosslink gelatin microspheres and comparison was done with glutalardehye. However, the crosslinking efficiency with rutin was reported to be low and moreover, it was revealed that the glutaraldehyde crosslinked microspheres were also safe as the microspheres crosslinked with rutin $^{32}$. In orders to remove un-reacted glutaraldehyde, microspheres were washed several times with water.

\section{Influence of formulation composition on Percent drug entrapment efficien cy (Y1)}

Percent drug entrapment efficiency increased from $60.37 \pm 1.85$ to $88.24 \pm 2.46 \%$ as the concentration of polymers increased. From response surface curve it was interpreted that the encapsulation efficiency of drug increases with the increase in polymer concentration. The polynomial equation correlating percent drug entrapment efficiency with independent variables is as follows;

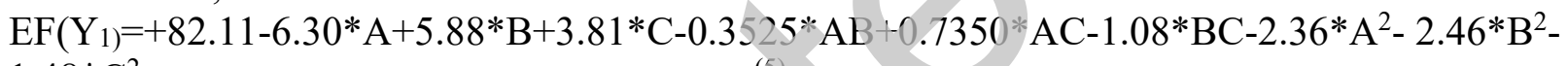

Where $\mathrm{A}$ is the volume of GA, while B and $\mathrm{C}$ is the amount of, pullulan and sterculia foetida respectively. Randomized Central Composite Design showed good fit. High F-Value of 28.94 and P-Value less than 0.0500 indicates that the model is significant.

The effect of independent formulation variables on entrapment efficiency is presented by response surface plots as shown in figure no. 1(a) respectively. The increase in entrapment efficiency may be due to high viscosity of the polymer-blend which consequently reduced the drug leaching from the microspheres during preparation. Also, high polymer concentration may cause a stronger entanglement of the drug inside the Sterculia foetida-pullulan network. However, encapsulation efficiency decreased with increase in GA concentration, this decrease might be due to increase in cross-linking density of polymer matrix which caused the formation of rigid structure with consequent reduction in free volume within the polymer matrix for entrapment of drug 33,34

\section{Influence of form ulation composition on in-vitro mucoadhesion}

The percent mucoadhesion in SGF of all batches was found between $60.78 \pm 1.62$ and $87.35 \pm$ $1.83 \%$. As the concentration of polymer increased mucoadhesion also also increased. The polynomial equation for \% mucoadhesion at $12 \mathrm{~h}$ in SGF (pH 1.2) was calculated as follows.

$$
\% \text { Mucoadhesion }=+76.072 .81 * \mathrm{~A}+6.59 * \mathrm{~B}+3.86 * \mathrm{C}
$$

The Model F-value of 35.43 and $\mathrm{P}<0.05$ implies the model is significant. Predicted $\mathrm{R}^{2}$ of 0.7856 is in reasonable agreement with adjusted $R^{2} 0.8446$ i.e. the difference is less than 0.2 . The effect of independent formulation variables on mucoadhesion (\%) is presented by response surface plots as shown in figure no. 1(b). Increase in mucoadhesion may be due to increase in number of hydroxyl groups of the hydrophilic polymers that could attach to the mucus membrane by hydrogen bonding with similar groups on biological substrate thus increasing the bond strength $^{29}$. Mucoadhesion decreases with increase in GA concentration. The decrease in mucoadhesion may be due to the rigid crosslinked polymer network, ensuing in decreased swelling and weaker interactions with the mucosal surface. Mucoadhesive property of Sterculia foetida is due to its capacity of forming mucoadhesive bond with mucin and interpretation of polymer chain in the interfacial area ${ }^{2,33,34,}$ 
All the formulations showed sustained release of amoxicillin over $12 \mathrm{~h}$ in simulated gastric fluid ( $\mathrm{pH}$ 1.2). The cumulative drug release for different batches of crosslinked semi-IPN

microspheres after $12 \mathrm{~h}$ was found within the range of $60.32 \pm 2.09$ to $89.41 \pm 1.99 \%$ (Table no. 2 and figure no 7). An increase in polymer level exhibited lower drug release rate. The polynomial equation for percent drug release at $12 \mathrm{~h}$ was calculated using the equation;

Drug release $=+82.15-6.18 * \mathrm{~A}-4.17 * \mathrm{~B}-4.53 * \mathrm{C}+1.30 * \mathrm{AB}+0.1912 * \mathrm{AC}-0.2513 * \mathrm{BC}$

$$
-2.148 \mathrm{~A}^{2}-4.54 * \mathrm{~B}^{2}-3.23 * \mathrm{C}^{2}
$$

The effect of formulation variable on \% Drug release is presented by surface response plots in figure no. 1(c) respectively. Decrease in drug release rate may be attributed to increase of Sterculia foetida content in the blend membrane. Hydrophobicity of microsphere matrix increases with Sterculia foetida content due to increase in ester linkages and methyl groups Also, the reduction in drug release rate could be attributed to the decrease in molecular volume of Sterculia foetida in the polymer matrix due to its decreased swelling and hydration. The drug release pattern was also highly dependent on the GA concentration ${ }^{33}$. As the concentration of glutaraldehyde was increased from $2 \mathrm{ml}$ to $4 \mathrm{ml}$ drug release was decreased from $89.41 \pm 1.99$ $60.32 \pm 2.09 \mathrm{in} 12 \mathrm{~h}$. This behaviour may be due to reduced free volume spaces of the GA treated IPN matrices, which could restrict the drug diffusion through the polymer network ${ }^{34}$. The drug release followed Hixon Crowels kinetics as it showed maximum $\mathrm{R}^{2}(0.9964)$. Drug release mechanism followed super case-II ( $\mathrm{n}=1.33$ of Korsemeyr Peppas) i.e. by diffusion and chain relaxation. There could be dominant role of chain relaxation at later time points due to waning crosslink over the time.

\section{Optimization by desirability function}

Optimization process was carried out with the help of desirability function. Microparticles were prepared under model predicted optimal condition with glutaraidehyde $4 \% \mathrm{v} / \mathrm{v}$, pullulan $8.28 \% \mathrm{w} / \mathrm{v}$ and Sterculia foetida $2.14 \% \mathrm{w} / \mathrm{v}$. Optimization was done by applying constraints on the dependent variables to evaluate predictive power of the model. The response variables of the formulated MPs under optimized condition were in good agreement (low percent bias) with the predicted values ensuring reliability of the model (Table no. 3 ).

\section{Influence of formulation composition on particle size}

The microspheres obtained were found in the size range from $57.99 \pm 1.53$ to $121.90 \pm 1.38 \mu \mathrm{m}$. The changes in particle size due to formulation vatiables clearly indicate that size was depend on the amount of GA and polymer concentration. When amount of GA was increased the particle size was found to decrease. This may be due to increased crosslinking density responsible for squeezing of the internal phase to a higher extent with less void space. When G A quantity was fixed and polymer ratio increased, the particle size was found to increase this may be due to the higher entrapment of drug in voids present in the polymeric network and when drug concentration was increased it need more space in the polymeric network and voids.

\section{Characterization of APS-Microspheres}

\section{Fourier transforms infrared spectra}

Figure no. 2 Demonstrates the FTIR spectra of amoxicillin trihydrate showing peaks at 1616.24 $\mathrm{cm}$ for aromatic $\mathrm{C}=\mathrm{C}$ stretching, $1685.67 \mathrm{~cm}^{-1}$ and $1577.66 \mathrm{~cm}^{-1}$ for $\mathrm{C}=\mathrm{O}$ stretching and $\mathrm{N}-\mathrm{H}$ deformation of amide respectively.

The absorption band at $1774.39 \mathrm{~cm}^{-1}$ was due to $\beta$-lactum $\mathrm{C}=\mathrm{O}$ stretching, whereas the absorption band at 2968.24 and $3039.60 \mathrm{~cm}^{-1}$ corresponds to $\mathrm{C}-\mathrm{H}$ Stretching for $\mathrm{CH}_{3}$ and aromatic C-H Stretching. All the prominant peaks of amoxicllin trihydrate were found intact in the spectrum of physical mixture with Sterculia foetida and pullulan suggesting no possible interaction of drug with polymer. FTIR spectrum of APS-MPs formulation revealed a broad absorption band from 3527.56 to $3105 \mathrm{~cm}^{-1}$ due to $\mathrm{OH}$ group of Sterculia foetida and $\mathrm{CHO}$ group of glutraldehyde which proves the formation of GA crosslinked semi-IPN microspheres. Also, bands from 3475 to $3620 \mathrm{~cm}^{-1}$ due to O-H stretching in the FTIR spectrum of Sterculia foetida had shifted to the lower wave number from 3423 to $3519 \mathrm{~cm}^{-1}$ in the FTIR spectrum of APSMPs. This shifting can be attributed to the hydrogen bond formation between Sterculia foetida and amoxicillin in the microspheres. Similar finding has been reported by Okur NU et al. ${ }^{35}$ 


\section{Differential scanning calorimetric studies}

Differential Scanning Calorimetry technique was used for taking thermograms of amoxicillin, pullulan, Sterculia foetida gum, physical mixture of Sterculia foetida-pullulan with amoxicillin trihydrate and ASP-MPs was shown in figure no. 3. Pure drug exhibited characteristic broad peak starting from 60 to $140^{\circ} \mathrm{C}$ due to dehydration of trihydrate and a broad endothermic peak starting from 185 to $210^{\circ} \mathrm{C}$ with peak at $199^{\circ} \mathrm{C}$ due to melting. DSC of pullulan depicted endothermic peak from 0 to $110^{\circ} \mathrm{C}$ while Sterculia gave endothermic peak from 0 to $110^{\circ} \mathrm{C}$ due to dehydration. The endothermic peak of amoxicillin trihydrate due to loss of water molecule is revealed in the DSC of physical mixture showing lack of incompatibility while the melting endothermic peak is diminished due to masking of drug in the polymers. The absence of characteristics endothermic peak of amoxicillin in the DSC thermogram of ASP-MS might be due to entrapment of drug in the microspheres due to which it could not be detected.

\section{X-ray diffraction}

X-ray diffraction of drug showed sharp and intense peaks from $2 \mathrm{e} 10-30^{\circ}$ this indicates crystalline characteristic of the drug. The characteristic peaks present in drug from $2 \theta 15-30^{\circ}$ had broadened in MPS which indicates loss of crystallinity upon entrapment in MPs as shown in figure no. 4

\section{Scanning electron microscopy}

SEM was done to visualize morphological features of the resulting optimized ASP-MPs. image is given in figure no. 5. Formed microspheres appear to be slightly irregular, aggregated with the rough surface. The rough surface might be due to the shrinkage of crossinked Sterculia gum during drying of IPN microspheres.

\section{In vivo radiographic studies}

$\mathrm{X}$-ray photographs revealed presence of microspheres in the stomach at $6 \mathrm{~h}$ post administration. The ASP-MPS could be seen retained for prolong time due to mucoadhesion to the stomach mucosal lining (figure no.7).

\section{Conclusion}

Semi-interpenetrating polymer network microspheres loaded with amoxicillin trihydrate were successfully prepared using Sterculia foetida and pulluian gum by emulsion crosslinking method using GA as the crosslinker. Microspheres prepared under optimized condition $(2.14 \% \mathrm{w} / \mathrm{v}$ Sterculia foetida, $8.28 \% \mathrm{w} / \mathrm{v}$ pullulan, $4 \% \mathrm{v} / \mathrm{v}$ glutaraldehyde) showed entrapment efficiency, drug release and mucoadhesion similar to the predicted values with low percent bais. $\mathrm{X}$-ray photographs revealed presence of microspheres for $10 \mathrm{~h}$. Thus, the prolonged retention of microspheres in the stomach with sustained drug release could effectively act against the $\mathrm{H}$ pylori reservoir in the stomach and improve the therapeutic effectiveness of amoxicillin trihydrate against $H$-pylori.

\section{REFERENCES}

1 S. Benita, Microencapsulation: methods and industrial applications. Marcel Dekker Inc., New York :1996

2 Patil S, Gokul S,Talele. Gastroretentive mucoadhesive tablet of lafutidine for controlled release and enhanced bioavailability. Drug Deliv.2015; 22: 312-319.

3 Arora S, Bisen G, Budhiraja RD. Mucoadhesive and muco-penetrating delivery for eradication of helicobacter pyroli. 2012; 6:18-30

4. Patel J, Patel MM. Stomach Specific Anti-Helicobacter Pylori Therapy: Preparation and Evaluation of Amoxicillin-Loaded chitosan mucoadhesive Microspheres. Current Drug Delivery.2007; 4: 41-50

5. Liu Z, Lua W, Qian L, Zhang X, Zeng P, Pan J. In vitro and in vivo studies on mucoadhesive microspheres of amoxicillin.Journal of Controlled Release, 2005:102: 135-144

6 Rajinikanth PS, karunagaran LN, Balasubramaniam J, Mishra B. Formulation and evaluation of Clarithromycin microspheres for eradication of Helicobacter pylori. Chem. Pharm. Bull. 2008; $56: 1658-1664$

7 Gabriel A, Janeth MV, Ana claudia LC, Alberto J. Karaya gum: General topics and applications, Macromolecules.An Indian Journal microreview. 2013; 9:111-116 8. Phillips GO, Williams PA, Handbook of hydrocolloids. Second edition Edited by ; Woodhead Publishing Limited, 1003 (2009). 
9. Anderson DMW, Wang WP (1994) The tree exudate gums permitted in foodstuffs as emulsifiers, stabilisers and thickeners. Chem Ind Forest Products 14:73-83

10. Singh B, Sharma N (2011) Design of sterculia gum based double potential antidiarrheal drug delivery system. Colloids Surf B: Biointerf 82:325-332

11. Bera H, Boddupalli S, Nayak A. Mucoadhesive-floating zinc-pectinate-sterculia gum interpenetrating polymer network beads encapsulating ziprasidone $\mathrm{HCl}$, Carbohydrate Polymers.2015;131: 108-18

12. Prajapati VD, Jani GK, Khanda SM. Pullulan: an exopolysaccharide and its various applications. Carbohydr Polym. 2013; 5: 95:540-9.

13. Long Yua,b, Katherine Deana, Lin Lib., Polymer blends and composites from renewable resources. Prog. Polym. Sci.2006; 31:576-602.

14. Dias RJ, Ghorpade VS, Havaldar VD, Mali KK, Hindurao N. Development and optimization of interpenetrating network beads of Delonix regia gum and sodium alginate using response surface methodology.Journal of Applied Pharmaceutical Science. 2015; 5: 056-064.

15. Nakay AK, Hasnain MS, Pal D, Gelled microparticles/Beads of sterculia gum and tamarind gum for sustained drug release. Polymer gel: 361-415

16. Mohamadnia Z, Zohuriaan Mehr MJ, Kabiri K. pH-Sensitive IPN hydrogel beads of carrageenan-Alginate for controlled drug delivery.Journal of Bioactive and Compatible

polymers. 2007; 22: 342-256

17 Prajapati, V. D, Jani, G. K, Moradiya, N. G., Randeria, N., P., Maheriya, P. M., and Nagar,B.

$\mathrm{J}$. Locust bean gum in the development of sustained release mucoadhesive macromolecules of aceclofenac, Carbohydrate Polymers. 2014; 113: 138-48

18. Mallikarjuna Reddy K, Ramesh Babu V, Sairam M, Subha M. C. S., Mallikarjuna N. N., Kulkarni P. V. \& Aminabhavi T. M., Development of chitosan-guar gum_semiinterpenetrating polymer network microspheres for controlled release of cefadroxil, Designed Monomers and Polymers. 2006; 9:491-501

19. Ray S, Banerjee S, Maitis S, Laha B, Barik S, Sa B, Bhattacharyya UK.Novel

interpenetrating network microspheres of xanthan gum-poly (vinyl alcohol) for the delivery of diclofenac sodium to the intestine-invitro and in vivo evaluation in Drug Delivery. 2010; 17 : 508-19

20. Kulkarni, R. V., Mutalik, S., Mangond, B. S., \& Nayak, U.Y. Novel interpenetrated polymer network microbeads of natural polysaccharides for modified release of water soluble drug: invitro and in-vivo evaluation. Journal of Pharmacy and Pharmacology.2012; 64: 530-540.

21. Nayak A, Pal D, Santra K. Deyelopment of calcium pectinate-tamarind seed polysaccharide mucoadhesive beads containing metformin HCl. Carbohydrate Polymers. 2014; 101: 220-230

22. Hoodaa $\mathrm{A}$ et al, Optimization and evaluation of gastroretentive ranitidine $\mathrm{HCl}$ microspheres by using design expert software. International Journal of B Macromolecules.2012; 51: 691-700. 23. venkateswaramurthy N, Sambathkumar R, Perumal P. Design development and evaluation of amoxicillin trihydrate mucoadhesive microspheres for helicobactor pylori eradication therapy.International Journal of Applied Pharmaceutics. 2010: 2:23-25.

24. P. Costa, L.J.M. Sousa, Modelling and comparison of dissolution profiles. Eur. J. Pharm.

Sci.2001:13, 123-133.

25. Costa FO, Sousa JJ, Pais AA, Fornosinho SJ. Comparison of dissolution profile of ibuprofen pellets. J. Control. Release. 2003:89, 199-212.

26. T. Higuchi, Mechanism of sustained action medication theoretical analysis of rate of release of solid drugs dispersed in solid matrices. J Pharm.Sci.1963; 52:1145-1149.

27. N.A. Peppas, Analysis of fickian and non-fickian drug release from polymers. Pharm. Acta. Helv, 1985; 60:110-111

28. Jain A, Pandey V, Ganeshpurkar A, Dubey N, \& Bansal D. Formulation and characterization of floating microballoons of Nizatidine for effective treatment of gastric ulcers in murine model, Drug Delivery, $2015 ; 22: 306-311$

29. Montgomery, D. C. Design and Analysis of Experiments, fifth ed. Wiley, New York.2001 30. Montgomery, D.C., Introduction to Statistical Quality Control, fourth ed. Wiley India (P) Ltd., New Delhi: 2008

31. Srivastava AK, Wadhwa S, Ridhurkar D, Mishra M. Drug Development and Industrial Pharmacy.2005; 31: 367-374.

32. Fabiana G, Thalita MC, Camila AO, Daniela DP, Michele GI, Joana M, Catarina R, Vladi OC, Telma MK, Maria VR, André R, Gelatin-based microspheres crosslinked with glutaraldehyde and rutin oriented to cosmetics, Brazilian Journal of Pharmaceutical Sciences ; 2016; 52:603-612 
33. Yadav, HK, Raizaday A, Kumar, S. H, Kasina S, Navya M., and Tashi C., Development of ph sensitive microparticles of karaya gum: by response surface methodology, carbohydrate polymers .2015; 134: 353-363.

34. Bera H, Boddupalli S, and Nayak AK. Mucoadhesive-floating zinc-pectinate-sterculia gum interpenetrating polymer network beads encapsulating ziprasidone $\mathrm{HCl}$. Carbohydrate Polymers. 2015;131108-18.

35. Neslihan ÜO, Nesrin H, Mehmet EO, Sule A, Aysegül Y, Panoraia I. Siafaka, Erdal C. An alternative approach to wound healing field; new composite films from natural polymers for mupirocin dermal delivery.Saudi Pharmaceutical Journal 2019; 27: 738-752

Table No. 1. Levels of process variables used in experiments

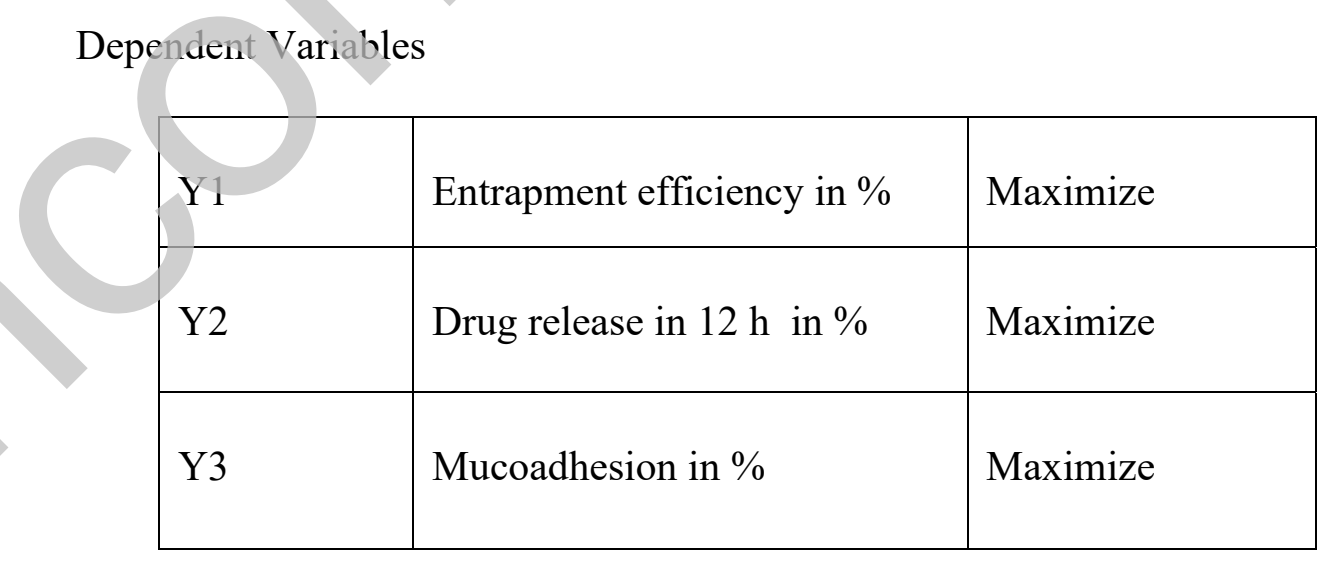

Table No (2). Design matrix and measured response 


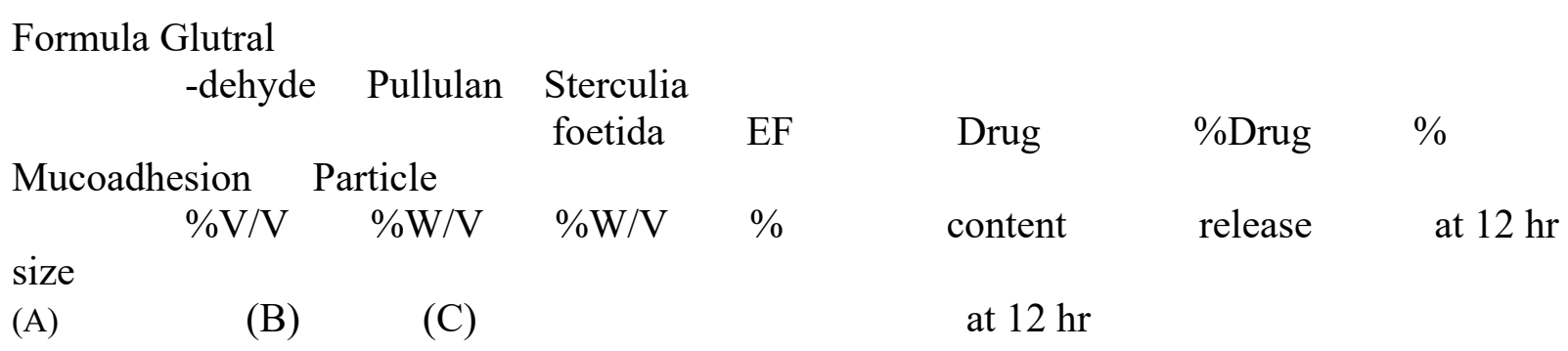

\begin{tabular}{|c|c|c|c|c|c|}
\hline APS-1 & $4 \quad 10$ & 4 & $88.12 \pm 1.16$ & $33.50 \pm 2.25$ & $70.23 \pm 2.59$ \\
\hline $87.35 \pm 1.32$ & $117.48 \pm 1.05$ & & & & \\
\hline APS-2 & $4 \quad 10$ & 2 & $84.53 \pm 1.18$ & $30.52 \pm 2.82$ & $78.56 \pm 1.79$ \\
\hline $83.32 \pm 1.87$ & $111.75 \pm 0.76$ & & & & \\
\hline APS-3 & $6 \quad 7$ & 3 & $82.10 \pm 2.08$ & $29.54 \pm 2.11$ & $82.24 \pm$ \\
\hline $78.54 \pm 1.93$ & $84.53 \pm 1.21$ & & & & \\
\hline APS-4 & $8 \quad 10$ & 2 & $72.15 \pm 1.70$ & $25.36 \pm 1.17$ & $68.86 \pm$ \\
\hline $80.54 \pm 2.28$ & $94.73 \pm 1.28$ & & & & \\
\hline APS-5 & $4 \quad 4$ & 4 & $79.26 \pm 1.06$ & $28.23 \pm 1.85$ & $80.47 \pm 2$ \\
\hline $75.81 \pm 1.98$ & $77.34 \pm 0.93$ & & & & \\
\hline $\begin{array}{l}\text { APS-6 } \\
68.51 \pm 1.77\end{array}$ & $\begin{array}{cc}4 & 4 \\
69.94 \pm 1.14\end{array}$ & 2 & $73.60 \pm 1.67$ & $26.13 \pm 1.83$ & \\
\hline APS-7 & $8 \quad 10$ & 4 & $76.42 \pm 1.66$ & $27.82 \pm 2.04$ & $59.68 \pm 2.8$ \\
\hline $82.48 \pm 2.72$ & $92.46 \pm 1.12$ & & & & \\
\hline APS-8 & $9.36 \quad 7$ & 3 & $63.49 \pm 1.69$ & $20.43 \pm 1.78$ & $64.63 \pm 1.2$ \\
\hline $69.24 \pm 2.53$ & $60.70 \pm 0.82$ & & & & \\
\hline APS-9 & $6 \quad 7$ & 3 & $82.10 \pm 2.06$ & $29.54 \pm 1.65$ & $82.24 \pm 1.88$ \\
\hline $78.54 \pm 1.93$ & $84.56 \pm 1.07$ & & & & \\
\hline APS-10 & $6 \quad 7$ & 3 & $82.10 \pm 2.06$ & $29.54 \pm 1.65$ & $82.24 \pm 1.88$ \\
\hline $78.54 \pm 1.93$ & $84.56 \pm 1.07$ & & & & \\
\hline APS-11 & $6 \quad 7$ & 3 & $82.10 \pm 2.06$ & $29.54 \pm 1.65$ & $82.24 \pm 1.88$ \\
\hline $78.54 \pm 1.93$ & $84.56 \pm 1.07$ & & & & \\
\hline APS-12 & $6 \quad 7$ & 3 & $86.32 \pm 1.49$ & $31.93 \pm 1.95$ & $62.93 \pm 2.1$ \\
\hline $83.33 \pm 2.02$ & $105.67 \pm 1.45$ & & & & \\
\hline APS-13 & $\begin{array}{ll}6 & 1.9542\end{array}$ & & $62.38 \pm 1.57$ & $18.74 \pm 2.25$ & $75.31 \pm 2.1$ \\
\hline $62.29 \pm 1.37$ & $64.15 \pm 1.26$ & & & & \\
\hline APS-14 & $6>17$ & .3182 & $69.85 \pm 1.96$ & $21.45 \pm 2.27$ & $80.10 \pm 1.73$ \\
\hline $65.48 \pm 2.01$ & $65.99 \pm 1.17$ & & & & \\
\hline APS-15 & $2.62 \quad 7$ & 3 & $87.69 \pm 2.65$ & $32.56 \pm 2.21$ & $84.59 \pm 2.46$ \\
\hline $79.63 \pm 1.76$ & $96.76 \pm 0.72$ & & & & \\
\hline APS-16 & 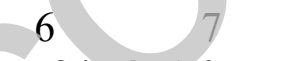 & 3 & $82.10 \pm 2.06$ & $29.54 \pm 1.65$ & $82.24 \pm 1.88$ \\
\hline $78.54 \pm 1.93$ & $84.53 \pm 1.07$ & & & & \\
\hline APS-17 & $6 \quad 7$ & 3 & $82.10 \pm 2.06$ & $29.54 \pm 1.65$ & $82.24 \pm 1.88$ \\
\hline $78.54=1.93$ & $84.53 \pm 1.07$ & & & & \\
\hline APS-18 & $8 \quad 4$ & 4 & $71.23 \pm 2.55$ & $23.26 \pm 2.11$ & $66.34 \pm 2.40$ \\
\hline $70.26 \pm 2.09$ & $65.70 \pm 1.36$ & & & & \\
\hline APS-19 & $8 \quad 4$ & 2 & $60.37 \pm 1.85$ & $16.64 \pm 2.06$ & $72.90 \pm 2.26$ \\
\hline $60.78 \pm 2.13$ & $57.99 \pm 1.53$ & & & & \\
\hline APS-20 & $\begin{array}{ll}6 & 12.0453\end{array}$ & 3 & $88.24 \pm 2.46$ & $34.80 \pm 2.20$ & $60.32 \pm 2.09$ \\
\hline $81.16 \pm 1.42$ & $121.90 \pm 1.38$ & & & & \\
\hline
\end{tabular}

*Volume of aqueous phase was $100 \mathrm{ml}$

Table No. (3) Optimization by desirability function

\begin{tabular}{|l|l|l|l|l|l|}
\hline Optimized & Optimized & Responses & Predictive & Experiment & $\%$ Bias \\
\hline
\end{tabular}




\begin{tabular}{|l|l|l|l|l|l|}
\hline formula & level & & value & al value & -2.06 \\
\hline Glutaraldehyde & $4 \% \mathrm{v} / \mathrm{v}$ & $\begin{array}{l}\text { Entrapment } \\
\text { efficiency (\%) }\end{array}$ & 88.751 & 86.92 & -1.81 \\
\hline Pullulan & $8.28 \% \mathrm{w} / \mathrm{v}$ & $\begin{array}{l}\text { Drug release in } \\
12 \mathrm{~h}(\%)\end{array}$ & 81.924 & 80.43 & -0.92 \\
\hline Sterculia foetida & $2.14 \% \mathrm{w} / \mathrm{v}$ & $\begin{array}{l}\text { Mucoadhsion( } \\
\%\end{array}$ & 82.498 & 81.73 & \\
\hline
\end{tabular}

Figures No. 1(a) 3D response surface plot graph showing the effect amount of pullulan and glutraldehyde on percent drug entrapment efficiency

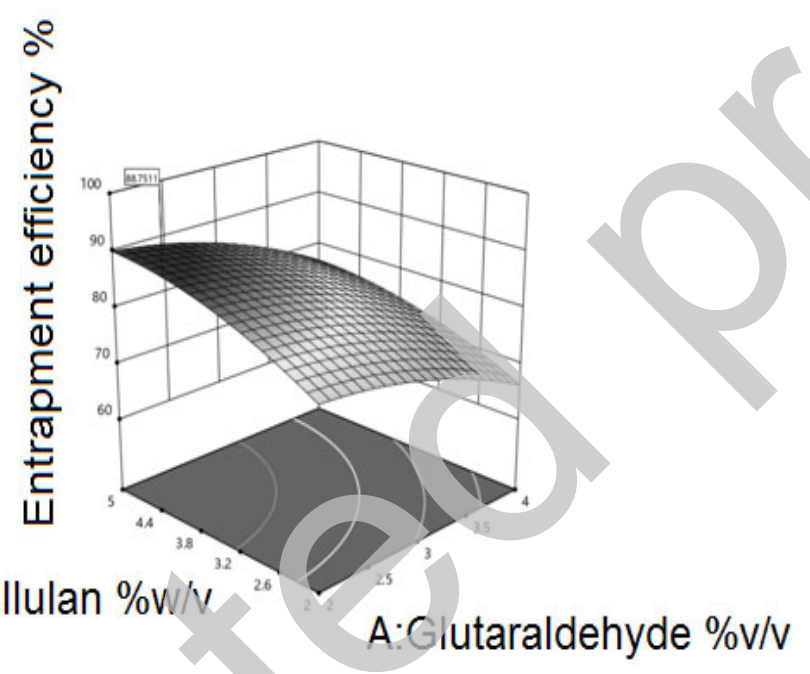

B: Concent. of pullulan $\% \mathrm{~W} / \mathrm{v} \quad$ A. Giutaraldehyde $\% \mathrm{v} / \mathrm{v}$

Figure No. 1(b) 3D response surface plot graph showing the effect amount of pullulan and glutiraldehyde on percent Mucoadhesion 


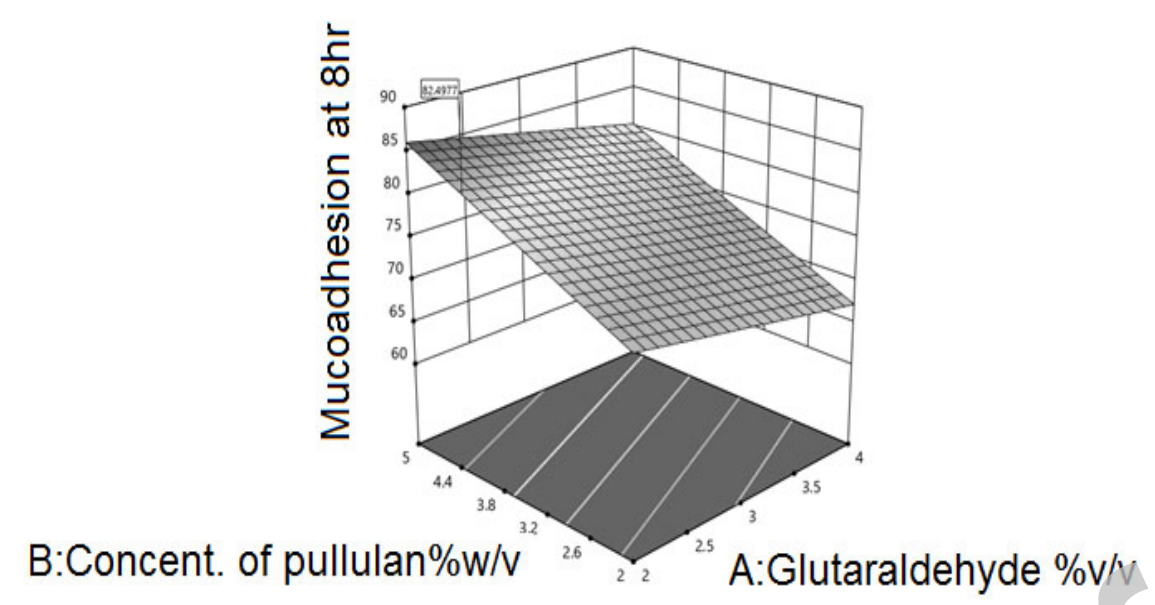

Figure No. 1(c) response surface plot graph showing the effect amount of pullulan and glutraldehyde on percent Drug release

\section{A:Glutaraldehyde \%v/v}

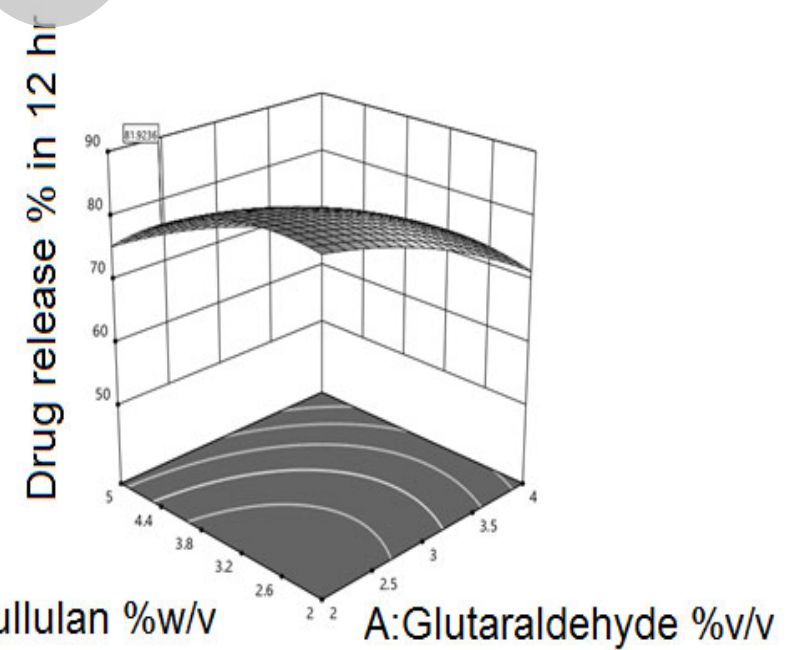


Figure No. (2) FTIR spectra of a) pure drug b) pullulan c) physical mixture of drug and polymers d) sterculia foetida e) optimized formulation

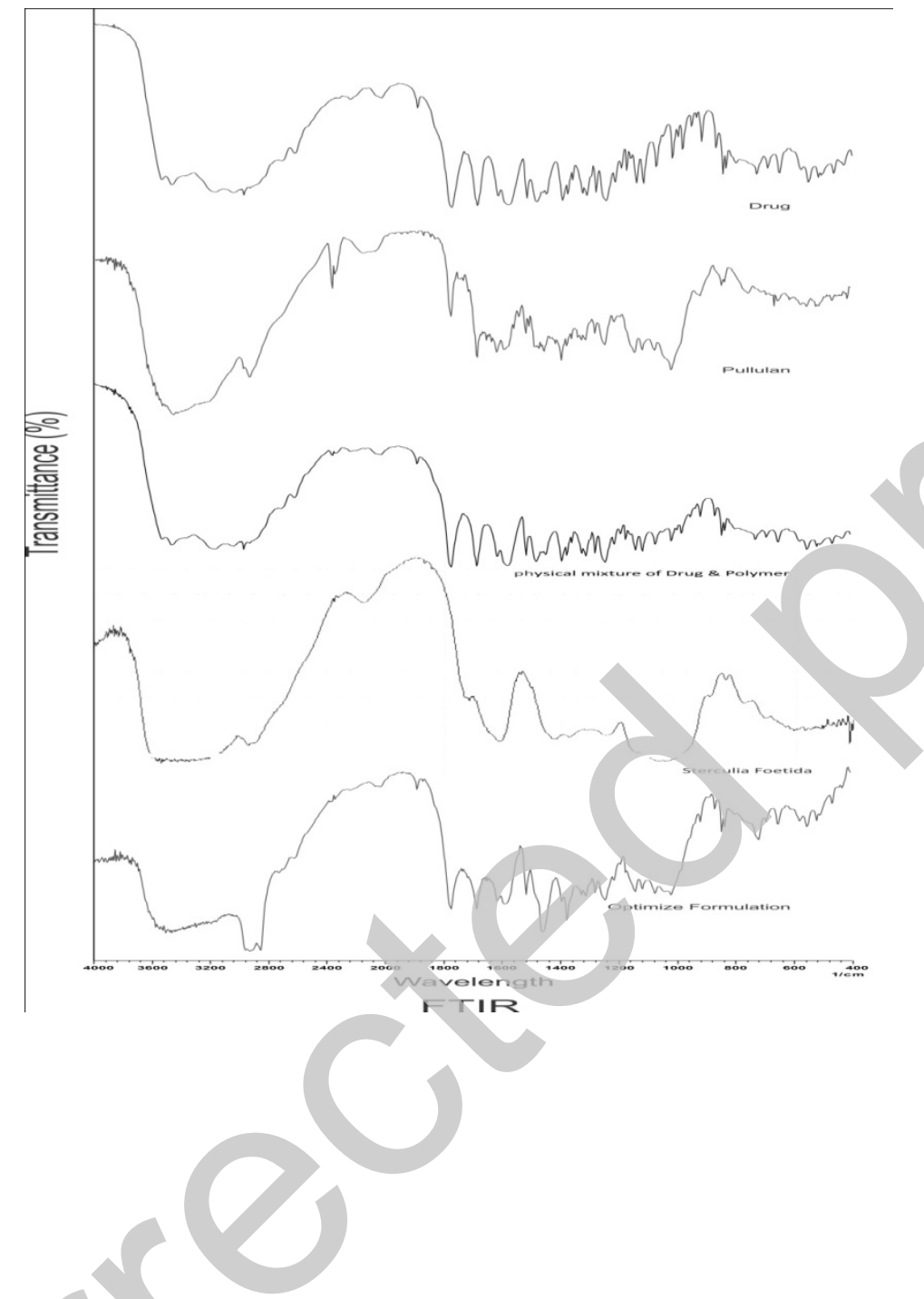

Figure No. (3) DSC thermogramme of 1) pure drug, 2) sterculia foetida 3) pullulan 4) physical mixture of drug and polymers 5) optimized formulation 


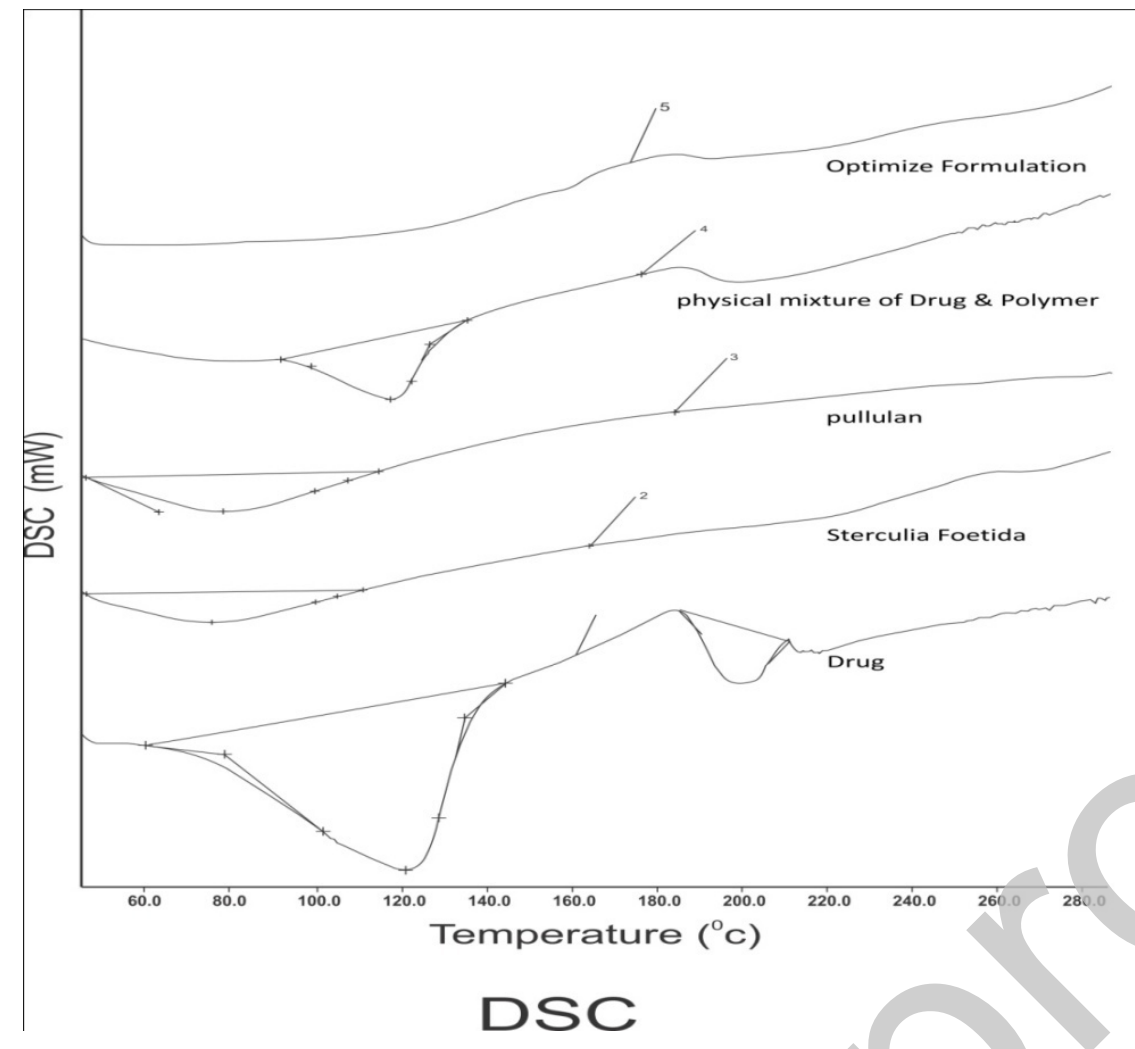

Figure No. (4) X-ray diffraction pattern of a) pure drug b) pullulan c) sterculia foetida d) optimized formulation

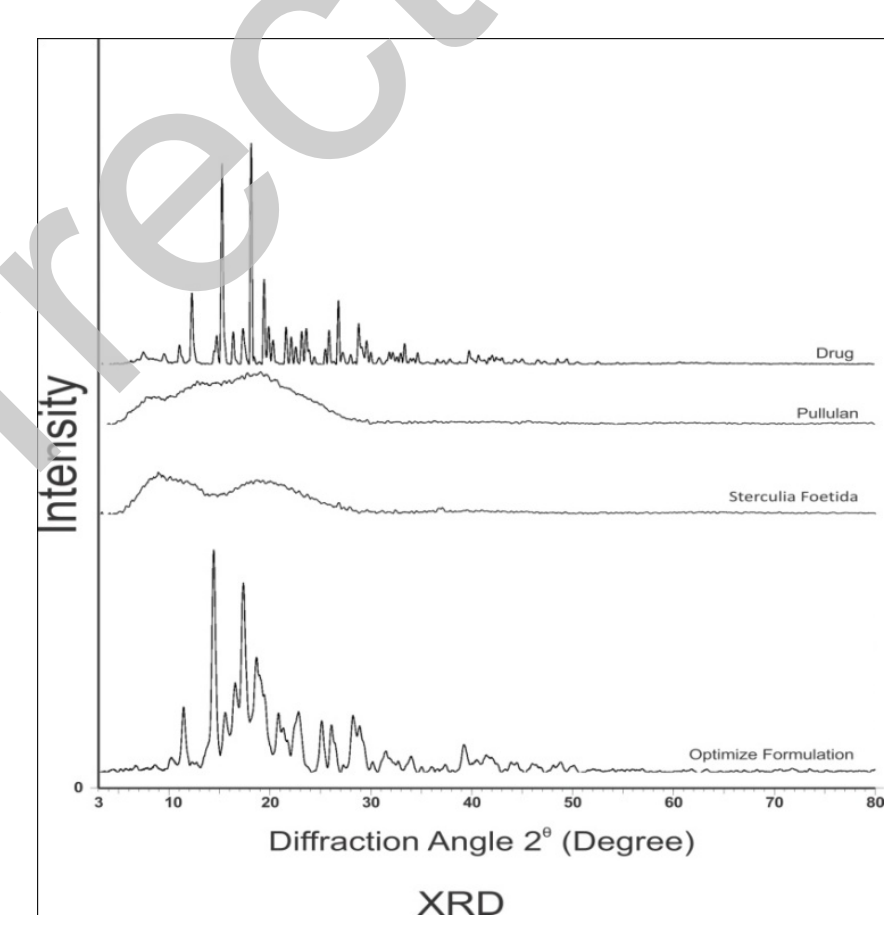

Figure No. ( 5 ) Scanning electron micrograph of optimized Stercculia foetida-pullulan microspheres containing amoxicillin trihydrate showing rough surface 


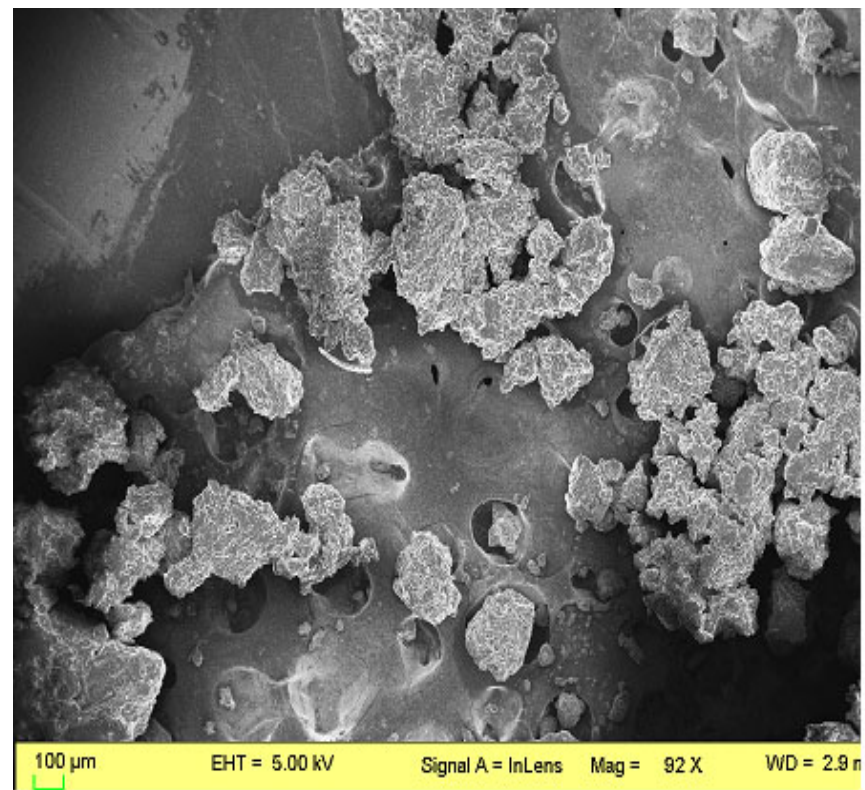

Figure no. (6) In- vitro drug release profile of Sterculia foetida-pullulan microspheres containing amoxicillin trihydrate in simulated gastric fluid $(\mathrm{pH} 1.2)($ mean \pm S.D.; $n=3)$

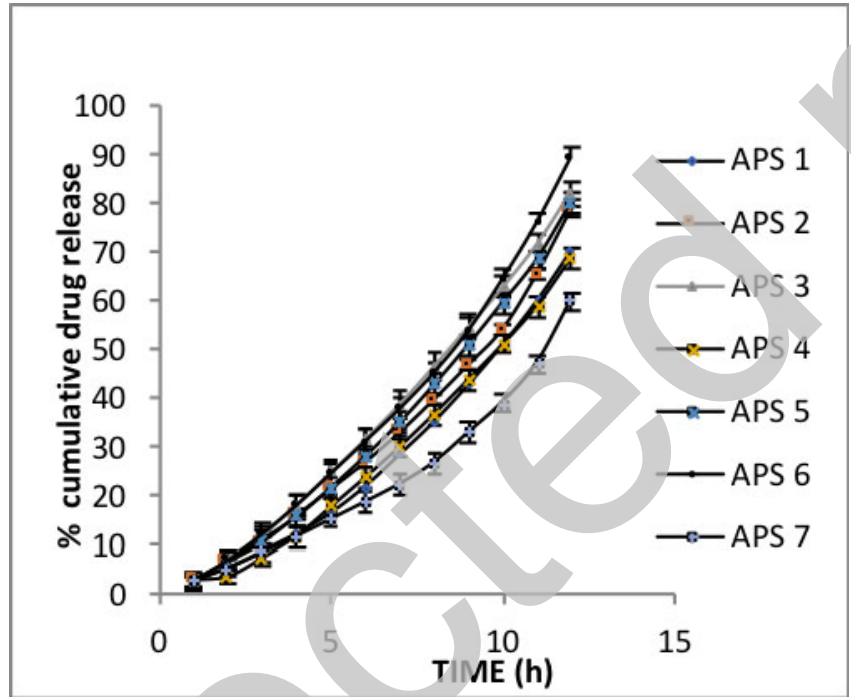

In-vitro release profile of batches APS1-APS7

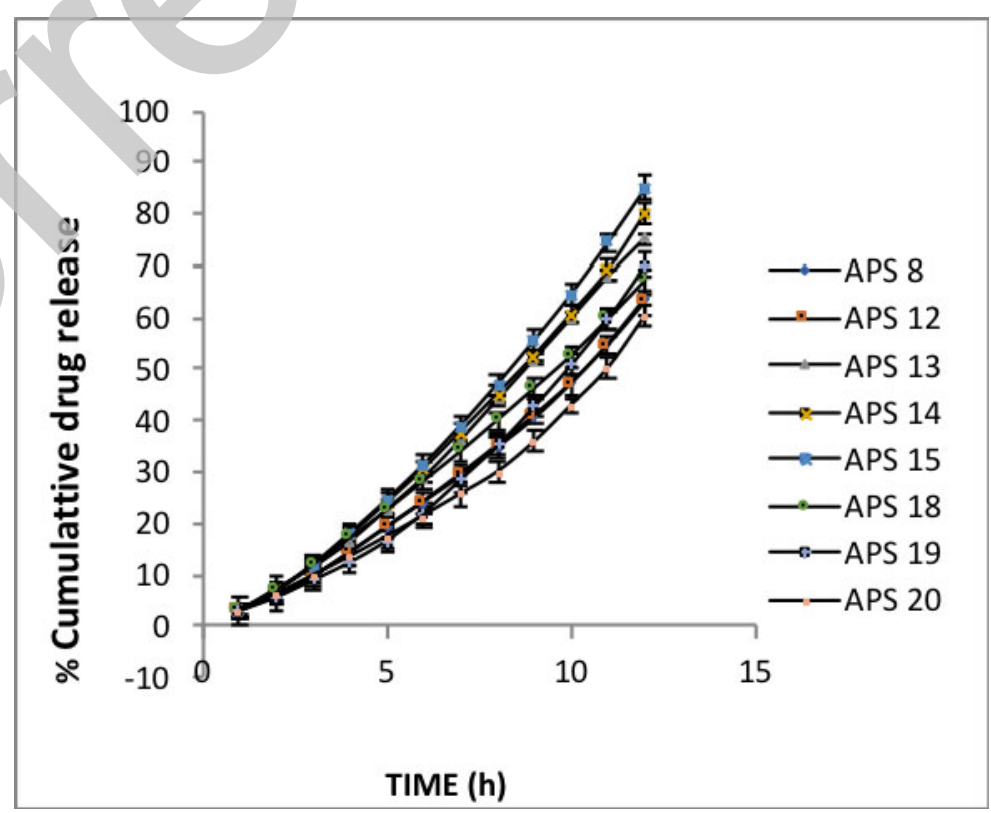

In-vitro release profile of batches APS8-APS20

Figure No. (7) - X-Ray photograph of microsphere in gastric region of rat
a)
$\mathbf{O h}$
b) $10 \mathrm{~h}$ 

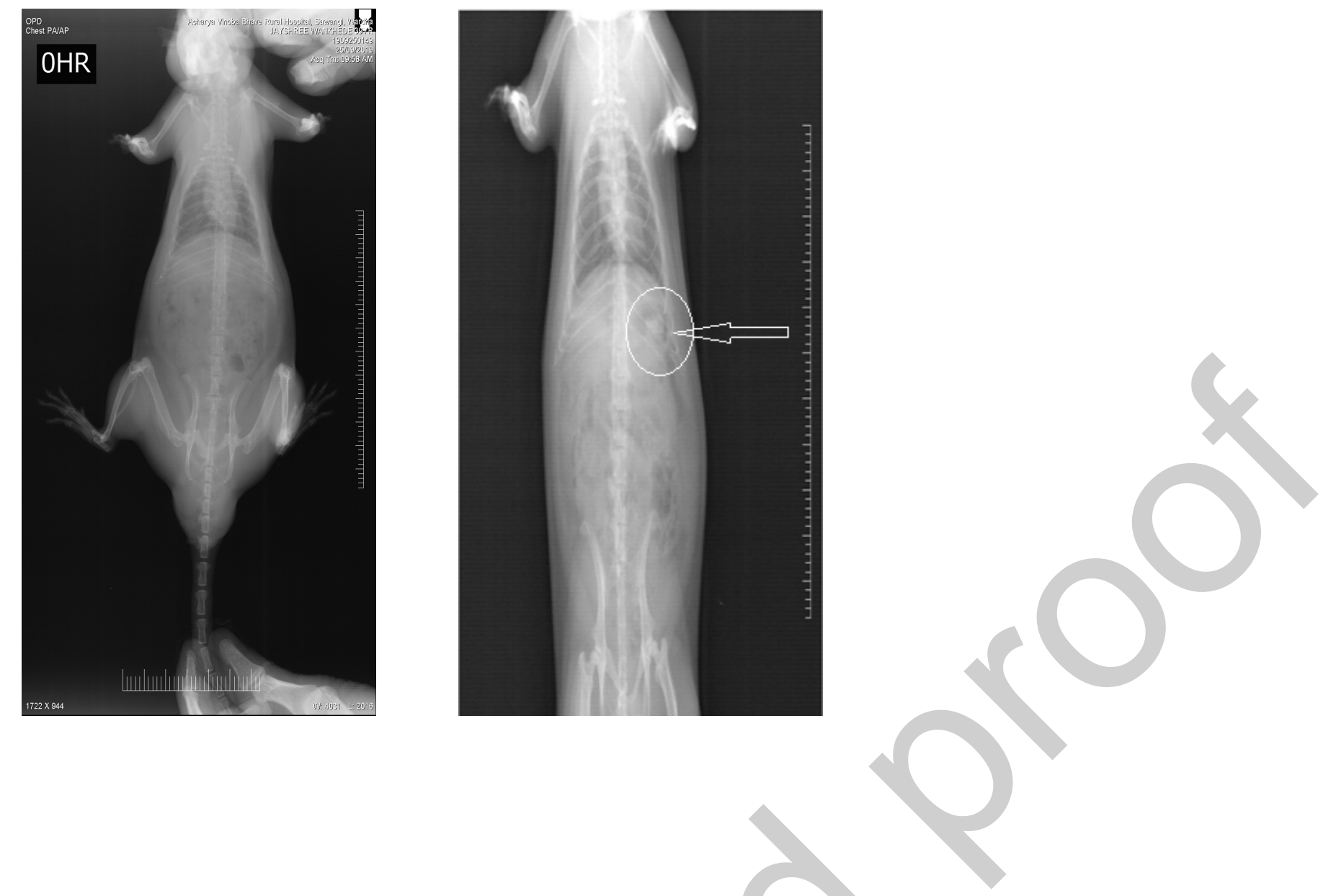


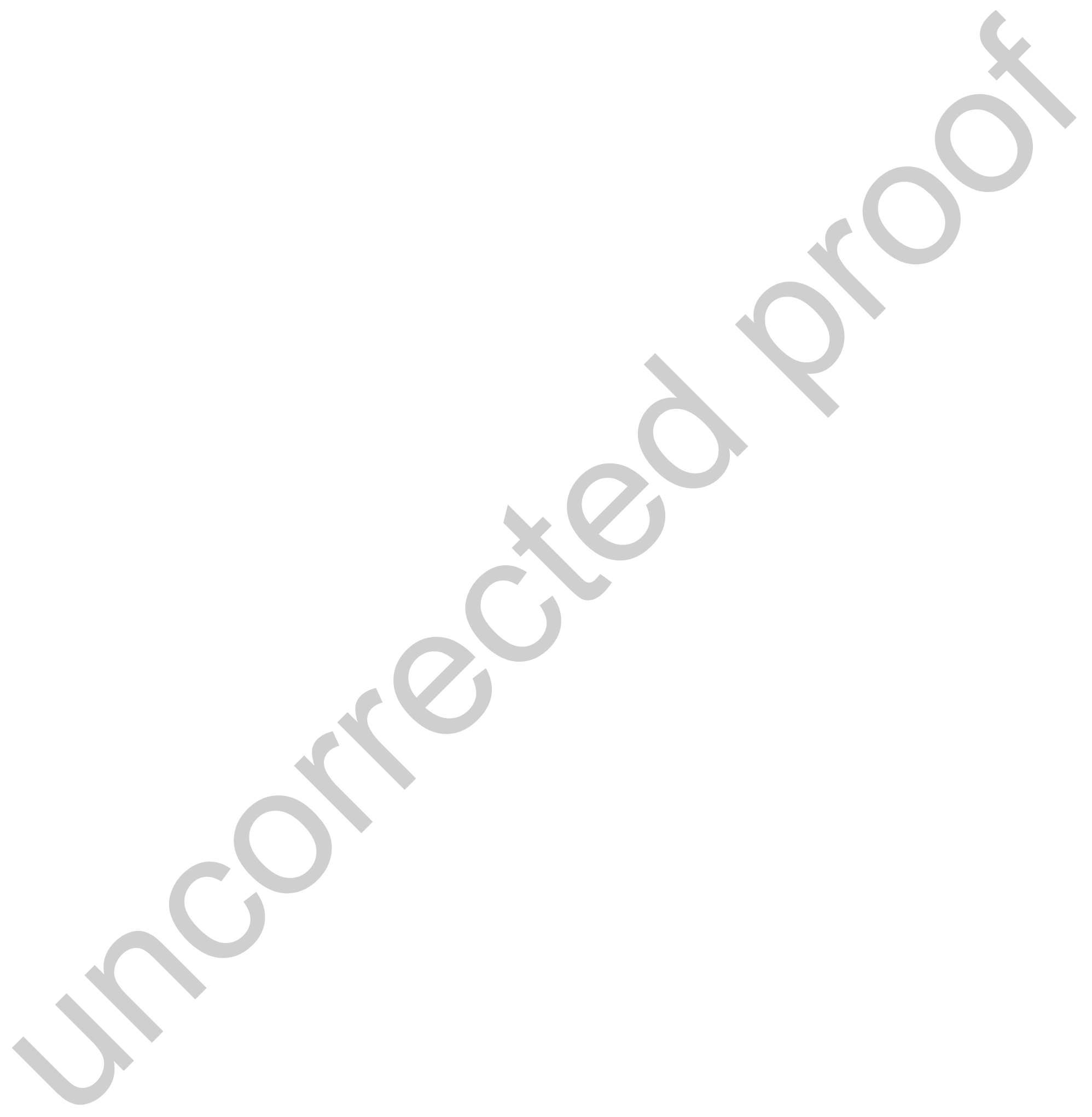

